\section{Mechanical Topping Mitigates Alternate Bearing of 'Kerman' Pistachios (Pistacia vera L.)}

\author{
L. Ferguson', J. Maranto, and R. Beede \\ Department of Pornology, University of California, Kearney Agricultural \\ Center, 9240 South Riverbend Avenue, Parlier, CA 93648
}

Additional index words. Pistacia atlantica, hedging, pruning, nut quality, blanks, shell splitting

\begin{abstract}
The effects of four mechanical pruning treatments [hedging, topping, hedging/ topping, and hand-pruning (control)] on nut yield, nut quality, alternate bearing, and growth of 14-year-old female 'Kerman' pistachio trees on Pistacia atlantica L. rootstocks were assessed. A single pruning was done before an "off," or low-crop, year followed by retopping of those treatments incorporating topping the first year. Over 7 years, yields of hedged/topped and topped trees were equal to those of control trees, while hedged trees produced significantly less. The incidence of nonsplit shells and blank nuts were not affected by pruning. Nuts weighed more all years for hedged/topped and topped trees than for the others. Alternate-bearing indices within 7 years were lower for pruning treatments incorporating topping. Topping mitigated the fluctuating annual vegetative growth pattern and resulted in $27 \%$ of the shoots retaining buds through three successive alternate-bearing cycles after the year of treatment. Hedged/topped and topped trees had significantly less alternation in annual girth growth than control or hedged trees. These results demonstrated that two successive seasons of mechanical topping, started before the off year, produced changes in shoot growth, trunk growth, and bud retention that mitigated alternate bearing through three biennial cycles, without decreasing yield. Thus, severe annual hand-pruning could be used to prevent or minimize alternate bearing of pistachios.
\end{abstract}

'Kerman', the only pistachio cultivar grown commercially in California's central San Joaquin Valley, is the third largest nut crop in California, with $>27,000$ bearing hectares. As with all pistachios, 'Kerman' is strongly alternate bearing. The most productive orchards exhibit alternate-bearing indices as high as 0.87 on a scale of 0 to 1 (no alternate bearing $=0$; total alternate bearing $=1)($ Wood, 1989). Alternate bearing of this magnitude disrupts marketing by precipitating strong fluctuations in net return to the grower and processor. Further, nut quality decreases when crop load is heavy. Heavy crops have significantly higher percentages of nuts with nonsplit shells than light crops. A recently observed shell deformation of unknown etiology has been positively correlated with crop load (Niven et al., 1994). Unlike citrus, annual fluctuations in crop load never have been demonstrated to damage the pistachio tree directly (Smith, 1976); however, MacDonald and Bolkan (1991) have observed increased tree death due

\footnotetext{
Received for publication 13 Mar. 1995. Accepted for publication 23 July 1995 . We gratefully acknowledge the assistance of Heraclio Crux, Jim Hatakeda, Ronald Fanucchi, Brian Blackwell, and Santiago Goana and Paramount Ranches. The cost of publishing this paper was defrayed in part by the payment of page charges. Under postal regulations, this paper therefore must be hereby marked advertisement solely to indicate this fact.

'To whom reprint requests should be addressed.
}

to the soilborne fungus Verticillium dahliae Kreb. following heavy crop years. Weinbaum et al. (1994) demonstrated a significant inverse relationship between carbohydrate and nitrogen storage and crop load, with "on" crops limiting storage of both. Mitigation of alternate bearing, therefore, would be desirable, particularly if it could be accomplished by normal orchard operations.

Crane and Nelson (1971) described the biennial phenology of alternate bearing in pistachios under California's Central Valley conditions. If the crop borne on 1-year-old shoots is heavy, then flower buds on the current-year's shoot growth abscise as the nutmeat enlarges. Flower buds do not abscise on shoots without nuts. Since pistachio shoot growth is remarkably uniform, there is little crop the subsequent season. Virtually all flower buds are retained during the subsequent "off' year and a heavy crop is set the next season, thus alternate bearing is increased.

While the seasonal phenology of alternate bearing is well characterized, the bearing mechanism remains obscure. Investigations into mechanisms of alternate bearing have focused on competition for nutrients (Crane and Al-Shalan, 1977; Crane et al., 1973, 1976; Goldschmidt and Golomb, 1982; Takeda et al., 1980) or an abscission signal from associated fruit clusters to the developing buds (Crane and Nelson, 1972). Rootstock also may have an effect on alternate bearing (Crane and Iwarkiri, 1986).

Methods for mitigating alternate bearing in tree crops include applications of growth regulators to remove fruit clusters or fruit within the clusters, changing developing buds from fruiting to vegetative, and decreasing bud abscission. Hand thinning, branch girdling, manipulating harvest date, and pruning also are used (Monsehse and Goldschmidt. 1982). Since pistachios in the United States have relatively small economic value, growth regulators for control of alternate bearing likely will not to be registered. Additionally, Crane and Nelson (1972) suggested that some chemical thinners are ineffective or deleterious. Ferguson and Maranto ( 1989) demonstrated that 2,4-dichloro-phenoxy acetic acid prevented bud abscission, but the buds died before the next season. Hand thinning and branch girdling are impractical. Earlier harvesting decreases the percentage of shell splitting, the major quality factor. Pruning, therefore, appears to be the best option for controlling alternate bearing of pistachios.

Wolpert (1986) reported that severe dormant pruning after an on year generated strong vegetative growth during the subsequent off year. Heading this strong vegetative flush after the off year would be expected to produce lateral growth with flower buds during the on year and hence a larger crop the following off year. Mechanical pruning is the most efficient way to prune severely.

This study reports the influence of several types of mechanical pruning on vegetative growth, nut yield, and nut quality of pistachio.

\section{Materials and Methods}

The experiment was conducted in a uniform 65-ha block of 14-year-old 'Kerman' trees planted north-south on a Pacheco sandy loam soil, with $P$. vera cv. Peters as pollinators planted every third tree in every third row. This arrangement produced an 8 female : 1 male ratio, with every female tree adjacent to a male. All trees were field-budded on $P$. atlantica rootstocks at a spacing of $1.6 \mathrm{~m}$ within rows and $1.9 \mathrm{~m}$ between rows to produce 316 trees (276 bearing trees) per hectare. Trees were headed at $1 \mathrm{~m}$ with three to five major scaffolds retained. Trees were maintained with standard industry irrigation, fertilization, pest and weed control practices, mechanical harvesting, and dormant handpruning practices after the 1985 and 1986 mechanical pruning treatments.

The design consisted of five completely randomized blocks (each with twelve 176-tree rows) and three mechanical pruning treatments plus a control. The experimental units were composed of three rows, with the middle rows being the data rows. Treatment rows were selected to exclude male pollinators from the center data collection row. Prunings were carried out 15 Jan. 1985 and 17 Jan. 1986. Hedging was done with five 1-m-diameter circular saws revolving at 1200 to $1400 \mathrm{rpm}$ on fixed vertical parallel arms at a ground speed of $11.3 \mathrm{~km} \cdot \mathrm{h}^{-1}$ or $5.7 \mathrm{ha} \cdot \mathrm{h}^{-1}$. Topping was done using fixed, 2-m, horizontal, buzz-saw blades moving at the ground speed noted. Pruning cuts were made into 3- to 4-year-old wood. 
Topping height was set at $3 \mathrm{~m}$ and hedging distance was set at $1.5 \mathrm{~m}$ from the trunks on both sides of the alley. Hedging or topping alone required a single machine pass. Hedging and topping together required one pass of each machine. Control trees were hand-pruned using the standard industry mixture of selective heading and thinning cuts. By visual canopy estimate, the hand-pruning control treatment removed $\approx 5 \%$ of the wood in the tree canopy, topping $30 \%$, hedging $30 \%$, and hedging plus topping $\approx 40 \%$. Both treatments incorporating topping were retopped 17 Jan. 1986, removing $75 \%$ of the previous-season's shoot growth. Hedged trees responded less and did not require rehedging in 1986. All trees were handpruned using standard industry methods from 1987 through 1991.

Each central row was harvested mechanically to assess the effect of pruning type on yield. Fresh weight per row was obtained with a certified commercial scale. Wet weight per tree was calculated by dividing the row weight by number of trees per row. Fresh I-kg nut subsamples were collected during shaker harvest from each of the same 10 trees per data row each year. The trees were selected for representative mean trunk girth. The standard industry method for determining marketable yield was used for each subsample. Each subsample was weighed fresh, hulled, dried to $5 \%$ moisture, and weighed dry, and the percentage by weight of filled splits, nonsplits (undesirable), blanks, and culls was determined after cracking. Yield of dry in-shell splits, or marketable yield, per tree was calculated using these percentages. Nut size is defined (California Pistachio Commission, 1990) as numberof nuts $/ 28 \mathrm{~g}$. The alternate-bearing index (I), which defines the intensity of yield deviations for the seven successive experimental periods. was calculated for each treatment row by an evaluation of intensity of deviation in yield in successive years:

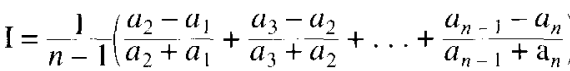

where $\mathrm{a}=$ yield in corresponding years and $\mathrm{n}$ $=$ number of years. If $\mathrm{I}=0$, there is no alternate bearing; if $\mathrm{I}=1.0$, there is total alternate bearing (Wood, 1989).

Trunk girths were measured annually in December at $0.5 \mathrm{~m}$ aboveground, on the same 10 subsample trees per row referred to above, to assess the effect of the pruning treatments on overall tree growth. The annual gain in girth was divided by the previous-year's girth to calculate the annual percentage increase. The effect of pruning on shoot growth and bud retention was determined by selecting another 10 representative (by mean girth) subsample trees per replication, pruning off, and weighing fresh the current-year's shoot growth. Shoot growth was then divided into growth with and without flowerbuds andreweighed separately. The percentage of shoots per tree retaining fruit buds was calculated as a percentage of total shoot growth weight. Data were analyzed using SAS 6.03 (SAS Institute, Gary, N.C.). Mean separation was performed using Duncan's new multiple range test.

\section{Results}

The effects of mechanical pruning on annual and cumulative per tree marketable yield of dry, in-shell split nuts demonstrated that topping mitigated alternate bearing without decreasing yield (Table 1). Over the seven years, trees that had been topped two successive years had yields equal to control trees. Hedged trees produced significantly less. These virtually equal yields among hedged/topped, topped, and control trees were generated by different annual-bearing patterns (Table 1). All mechanical pruning significantly decreased per-tree yield in 1985. However, from 1986 through 1991, topped and hedged/topped trees had less fluctuation in annual yield than hedged or control trees. Because of these differences in annual yields, the alternate-bearing indices also differed among treatments $(\mathrm{P}<0.05)$. There was no difference in alternate bearing between control and hedged trees, for which I was 0.88 and 0.79 , respectively, but topped and hedged/topped trees had I values of only 0.55 and 0.36 , respectively.

Topping and hedging/topping, and sometimes hedging, improved nut size (Table 2). Topped and hedged/topped trees consistently produced 25 nuts $/ 28 \mathrm{~g}$ vs. 26 nuts $/ 28 \mathrm{~g}$ for nuts from control or hedged trees. From 1987 through 1991, hedged trees also produced 25 nuts/28 $\mathrm{g}$ during the off years. There were few consistent, significant differences among treatments in the percentages of blank, split, nonsplit, and cull nuts within a harvest season (Table 2).

Topping and hedging/topping also affected the fresh weight of annual shoot growth (Table 3 ). In the years of treatment and the first year thereafter (1985, 1986, and 1987), topped and hedged/topped trees produced more shoot growth than the hedged or control trees. From 1988 to 1991, there were few consistent differences in shoot growth among treatments. However, topped and hedged/topped trees vs. hedged and control trees had distinctly different annual shoot growth patterns. Shoot growth from topped and hedged/topped trees declined steadily from 1986 through 1991. Shoot growth of hedged and control trees, except for a significant increase for hedged trees in 1985 and 1986, had alternating shoot growth typical of alternate-bearing trees.

Table 1. Effect of mechanical and hand-pruning on annual and cumulative nut yield (kilograms of in-shell splits per tree) from the year of treatment (1985) through three subsequent alternate-bearing cycles (1986-91)

\begin{tabular}{|c|c|c|c|c|}
\hline \multirow[b]{3}{*}{$\begin{array}{l}\text { Year and } \\
\text { cycle }\end{array}$} & \multicolumn{4}{|c|}{ Nut yield (kg/tree) } \\
\hline & \multicolumn{4}{|c|}{ Pruning method } \\
\hline & $\begin{array}{c}\text { Hedged/ } \\
\text { topped }\end{array}$ & Topped & Hedged & Control \\
\hline 1985 Off & $0.8 \mathrm{c}$ & $1.7 \mathrm{~b}$ & $2.1 \mathrm{~b}$ & $2.9 \mathrm{a}$ \\
\hline $1986 \mathrm{On}$ & $12.7 \mathrm{c}$ & $17.8 b$ & $20.0 \mathrm{a}$ & $22.1 \mathrm{a}$ \\
\hline 1987 Off & $6.4 \mathrm{a}$ & $5.3 \mathrm{a}$ & $3.4 \mathrm{~b}$ & $1.6 \mathrm{c}$ \\
\hline $1988 \mathrm{On}$ & $11.8 \mathrm{~b}$ & $11.0 \mathrm{~b}$ & $11.8 \mathrm{~b}$ & $15.3 \mathrm{a}$ \\
\hline 1989 Off & $5.1 \mathrm{a}$ & $2.7 \mathrm{~b}$ & $0.3 \mathrm{c}$ & $0.1 \mathrm{c}$ \\
\hline $1990 \mathrm{On}$ & $12.2 \mathrm{~b}$ & $13.7 b$ & $15.9 \mathrm{a}$ & $16.7 \mathrm{a}$ \\
\hline 1991 Off & $11.6 \mathrm{a}$ & $7.7 \mathrm{~b}$ & $1.9 \mathrm{c}$ & $1.4 \mathrm{c}$ \\
\hline $\begin{array}{l}\text { Cumulative } \\
(1985-91)\end{array}$ & $60.6 \mathrm{a}$ & $60.0 \mathrm{a}$ & $55.5 \mathrm{~b}$ & $60.1 \mathrm{a}$ \\
\hline
\end{tabular}

${ }^{2}$ Mean separation within rows by Duncan's new multiple range test $(P \leq 0.05)$.
Topping and hedging/topping had a significant effect on the percentage of shoot growth, by weight, producing or retaining fruit buds (Table 3). In the years of treatment (1985 and 1986), all mechanically pruned trees differed significantly in the percentages of shoots with fruit buds from control trees. During the off year (1985), mechanically pruned trees had significantly less shoot growth with fruit buds than control trees because mechanically pruned trees produced more vegetative wood. After the on year (i.e., in 1986), the mechanically pruned trees had significantly more shoot growth with fruit buds because there was less bud abscission. From 1987 through 1989, the topped and hedged/ topped trees had significantly less shoot growth after both off years (1987 and 1989) and significantly more after the on year (1988) than control and hedged trees. Hedged and control trees had about the same percentage of shoot growth with fruit buds from 1986 through 1991 and similar fluctuations in production between the on and off years. By 1990 and 1991, there were no significant differences among mechanically pruned and control trees in the percentage of shoot growth with buds.

Topping and hedging/topping, and hedging initially, significantly affected the annual percent increase in trunk girth among treatments (Table 4). All three mechanical pruning treatments resulted in significantly less girth growth during the off year and a significantly higher increase in girth growth during the on year. From 1987 through 1991, control and hedged trees had similar girth growth. However, these two treatments consistently resulted in more girth growth during off years and less during on years compared to topped 1990 is not explained.

Using the industry average price per pound paid the grower for marketable nuts during the years of this experiment, and subtracting the annual pruning costs, hedged/topped trees produced an average net return of U.S. \$598 more per hectare per year than control trees. Topped trees returned U.S. \$315 more per hectare per year than controls, and hedged trees returned \$398 less per hectare per year than controls. There were no other changes in production practices associated with these treatments. and hedged/topped trees. The aberration in 
Table 2. Effects of pruning method on nut size and percentage by weight of blank, split, nonsplit, and cull nuts. $^{2}$

\begin{tabular}{|c|c|c|c|c|c|}
\hline \multirow[b]{2}{*}{$\begin{array}{l}\text { Year, cycle, } \\
\text { and pruning } \\
\text { method }\end{array}$} & \multicolumn{5}{|c|}{ Nut characteristic } \\
\hline & $\begin{array}{c}\text { Size }^{y} \\
\text { (no./28 g) }\end{array}$ & $\begin{array}{c}\text { Blank } \\
(\%)\end{array}$ & $\begin{array}{c}\text { Split } \\
(\%)\end{array}$ & $\begin{array}{l}\text { Non- } \\
\text { split } \\
(\%)\end{array}$ & $\begin{array}{l}\text { Culls } \\
(\%)\end{array}$ \\
\hline \multicolumn{6}{|l|}{1985 Off } \\
\hline Hand (control) & $26 \mathrm{a}$ & $8.1 \mathrm{a}$ & $86 \mathrm{a}$ & $3.2 \mathrm{a}$ & $3.3 a$ \\
\hline Hedged & $26 \mathrm{a}$ & $7.2 \mathrm{~b}$ & $86 a$ & $3.0 \mathrm{a}$ & $3.7 \mathrm{a}$ \\
\hline Topped & $25 \mathrm{~b}$ & $8.4 \mathrm{a}$ & $85 a$ & $2.9 \mathrm{a}$ & $3.8 \mathrm{a}$ \\
\hline Hedged/topped & $25 \mathrm{~b}$ & $8.1 \mathrm{a}$ & $86 a$ & $2.7 \mathrm{a}$ & $3.4 \mathrm{a}$ \\
\hline Average & 26 & 8.0 & 86 & 3.0 & 3.6 \\
\hline \multicolumn{6}{|l|}{1986 On } \\
\hline Hand (control) & $26 \mathrm{a}$ & $2.1 \mathrm{a}$ & $63 a$ & $30 a$ & $4.1 \mathrm{a}$ \\
\hline Hedged & $26 \mathrm{a}$ & $2.5 \mathrm{a}$ & $65 \mathrm{a}$ & $28 a$ & $3.9 \mathrm{a}$ \\
\hline Topped & $25 \mathrm{~b}$ & $2.9 \mathrm{a}$ & $64 \mathrm{a}$ & $64 a$ & $2.6 \mathrm{a}$ \\
\hline Hedged/topped & $25 \mathrm{~b}$ & $2.6 \mathrm{a}$ & $62 a$ & $29 \mathrm{at}$ & $5.5 \mathrm{a}$ \\
\hline Average & 26 & 2.5 & 64 & 29 & 4.0 \\
\hline \multicolumn{6}{|l|}{1987 Off } \\
\hline Hand (control) & $26 \mathrm{a}$ & $10.1 \mathrm{ab}$ & $83 \mathrm{ab}$ & $3.7 \mathrm{a}$ & $5.6 \mathrm{a}$ \\
\hline Hedged & $25 \mathrm{~b}$ & $8.5 \mathrm{~b}$ & $84 a$ & $3.1 \mathrm{a}$ & $5.0 \mathrm{a}$ \\
\hline Topped & $25 \mathrm{~b}$ & $11.5 \mathrm{a}$ & $80 \mathrm{~b}$ & $3.7 \mathrm{a}$ & $4.8 \mathrm{a}$ \\
\hline Hedged/topped & $25 \mathrm{~b}$ & $10.2 a b$ & $83 \mathrm{ab}$ & $3.6 \mathrm{a}$ & $3.1 \mathrm{a}$ \\
\hline Average & 25 & 10.1 & 83 & 3.5 & 4.6 \\
\hline \multicolumn{6}{|l|}{$1988 \mathrm{On}$} \\
\hline Hand (control) & $26 a$ & $2.7 \mathrm{a}$ & $73 a$ & $20 a$ & $4.1 \mathrm{a}$ \\
\hline Hedged & $26 a$ & $2.8 \mathrm{a}$ & $73 a$ & $21 \mathrm{a}$ & $3.3 \mathrm{a}$ \\
\hline Topped & $25 \mathrm{~b}$ & $2.2 \mathrm{a}$ & $72 a$ & $22 \mathrm{a}$ & $3.1 \mathrm{a}$ \\
\hline Hedged/topped & $25 \mathrm{~b}$ & $2.2 \mathrm{a}$ & $73 a$ & $23 a$ & $2.5 \mathrm{a}$ \\
\hline Average & 26 & 2.5 & 73 & 22 & 3.3 \\
\hline \multicolumn{6}{|l|}{1989 Off } \\
\hline Hand (control) & $26 \mathrm{a}$ & $19.1 \mathrm{a}$ & $48 \mathrm{~b}$ & $19 \mathrm{a}$ & $14.3 \mathrm{a}$ \\
\hline Hedged & $25 \mathrm{~b}$ & $17.7 \mathrm{~b}$ & $61 \mathrm{a}$ & $13 \mathrm{~b}$ & $7.7 \mathrm{~b}$ \\
\hline Topped & $25 \mathrm{~b}$ & $14.1 \mathrm{c}$ & $64 a$ & $15 \mathrm{~b}$ & $7.2 \mathrm{~b}$ \\
\hline Hedged/topped & $25 \mathrm{~b}$ & $16.0 \mathrm{~b}$ & $64 \mathrm{a}$ & $13 \mathrm{~b}$ & $6.8 \mathrm{~b}$ \\
\hline Average & 25 & 16.7 & 60 & 15 & 9.0 \\
\hline \multicolumn{6}{|l|}{$1990 \mathrm{On}$} \\
\hline Hand (control) & $26 a$ & $11.2 \mathrm{a}$ & $67 a$ & 21 a & $0.1 \mathrm{a}$ \\
\hline Hedged & $26 a$ & $9.3 \mathrm{a}$ & $69 a$ & $22 \mathrm{a}$ & $0.1 \mathrm{a}$ \\
\hline Topped & $25 \mathrm{~b}$ & $11.7 \mathrm{a}$ & $63 a$ & $23 \mathrm{a}$ & $2.0 \mathrm{a}$ \\
\hline Hedged/topped & $25 \mathrm{~b}$ & $13.8 \mathrm{a}$ & $67 \mathrm{a}$ & $19 a$ & $0.1 \mathrm{a}$ \\
\hline Average & 26 & 11.5 & 67 & 21 & 0.6 \\
\hline \multicolumn{6}{|l|}{1991 Off } \\
\hline Hand (control) & $26 a$ & $19.2 \mathrm{a}$ & $59 a$ & $21 \mathrm{~b}$ & $0.7 \mathrm{a}$ \\
\hline Hedged & $25 \mathrm{~b}$ & $16.0 \mathrm{a}$ & $57 \mathrm{a}$ & $26 \mathrm{~b}$ & $0.9 \mathrm{a}$ \\
\hline Topped & $25 b$ & $15.1 \mathrm{a}$ & $50 \mathrm{c}$ & $34 a$ & $0.7 \mathrm{a}$ \\
\hline Hedged/topped & $25 \mathrm{~b}$ & $17.0 \mathrm{a}$ & $47 \mathrm{c}$ & $35 \mathrm{a}$ & $0.8 \mathrm{a}$ \\
\hline Average & 25 & 16.8 & 53 & 29 & 0.7 \\
\hline
\end{tabular}

${ }^{2}$ Mean separation within rows by Duncan's new multiple range test $(P \leq 0.05)$

${ }^{y}$ Size is based on the industry standard of number of nuts/28 g.

\section{Discussion}

Attempts to control alternate bearing in pistachio with methods other than pruning have been unsuccessful. Crane and Nelson (1972) and Ferguson and Maranto (1989) demonstrated that auxin application through midJune could prevent bud abscission, but the retained buds died within the season or were not adequately productive. (2-Chloroethyl) phosphonic acid (ethephon) to thin within the cluster was similarly ineffective (Crane et al., 1982). Wolpert's (1986) preliminary report that severe pruning decreased crop load and stimulated new vegetative growth prompted the hypothesis of the present investigation. $\mathrm{He}$ demonstrated that heading every terminal of a mature alternate-bearing pistachio tree produced a strong vegetative response. Heading the resulting vegetative flush the following dormant season should produce new lateral fruiting wood. To apply this theory to mitigate alternate bearing, vegetative growth would need to be generated the off year and be headed the next on year to generate lateral fruiting buds, which would produce crop the following off year. To achieve this result, pruning would have to be done during the dormant season before an off year and be sufficiently severe to generate a vegetative response. Severe pruning done before the off crop year would remove less crop than pruning during an on year and be more acceptable to growers. Beede et al. (1991, 1992) demonstrated that when $50 \%$ of pistachio fruit buds were removed before the on year, the tree completely compensated by producing more and larger nuts per cluster. Thus, pruning before the off year was the best time to mitigate alternate bearing.

This proposed alteration in shoot growth was precisely what the mechanical pruning treatments, particularly topping, achieved in this experiment. Topping alone, or combined with hedging, produced more regular annual shoot growth with less alternation in the percentage of wood retaining its buds. Increasing the regularity of production of shoot growth with buds resulted in more regular marketable yields. Furthermore, pruning treatments incorporating topping appeared to alter the carbohydrate storage status, as indicated by annual trunk girth increases of the tree. Generally, the higher the yield the smaller the increase in girth growth within a given season. In this experiment, pruning altered shoot growth, which, in turn, altered yield, and the combination of the two appeared to affect the carbohydrate storage of the tree as indicated by the girth growth. This proposed sequence of events is consistent with a recent report that tree cropping strongly, and inversely, influences carbohydrate and nutritional storage the following dormant season (Weinbaum et al., 1994).

The increase in nut size produced by topping is consistent with the results of Beede et al. (1992), which demonstrated that pistachio trees compensated for a decrease in floral buds by producing more and larger nuts on the remaining clusters. The heavier nuts produced by hedging/topping and topping are economically important, since 25 vs. 26 nuts/28 g is the California industry standard differentiating large- and medium-sized nuts,

Importantly, the percentage of blanks, nonsplits, and culls was not affected by the pruning treatments for all seven harvest seasons. Nonsplitting and blanking appeared to be more strongly correlated with on- and offyear tree status than with absolute crop load. Culls, generally a result of insect damage or harvest and postharvest practices, were independent of crop load. Both of these results are consistent with the data of Weinbaum et al. (1994), which showed significant differences in tree carbohydrate and nitrogen reserves when entering a crop year. These results suggest that tree carbohydrate storage capacity strongly influences the percentages of blanks and nonsplits and nut weight more than does absolute crop load (as quite different crop loads within a crop year produced similar percentages of blank and nonsplit nuts).

This study does not demonstrate how long the mitigation of alternate bearing would have persisted because the study was terminated in 1991. Since the differences in percentage of shoot growth retaining buds effectively dissipated by 1991 (Table 3, it would be expected that the mitigation of alternate bearing would not have persisted beyond 1991 .

The financial advantage produced by mitigating alternate bearing may dissipate in the future if the prices of marketable nuts cease fluctuating in response to annual yields. However, the advantage of more regular production with no yield reduction remains valid.

In summary, this study demonstrated that two sequential mechanical toppings, done before the off crop year, mitigated alternate bearing of pistachio trees through three alternate-bearing cycles. Mitigation appeared to be the result of shoot growth alteration. Although these treatments were mechanical, these data indicate that more severe annual handpruning, particularly if started before alternate bearing commences, could decrease the severity of alternate bearing in pistachios. 
Table 3. Effects of pruning method on annual shoot growth by fresh weight and percentage of shoots with fruit buds. ${ }^{2}$

\begin{tabular}{|c|c|c|c|c|}
\hline \multirow[b]{2}{*}{$\begin{array}{l}\text { Year, cycle, } \\
\text { and shoot growth }\end{array}$} & \multicolumn{4}{|c|}{ Pruning method } \\
\hline & $\begin{array}{l}\text { Hedged/ } \\
\text { topped }\end{array}$ & Topped & Hedged & Control \\
\hline \multicolumn{5}{|l|}{1985 Off } \\
\hline Total (kg) & $17.7 \mathrm{a}$ & $15.0 \mathrm{~b}$ & $8.9 \mathrm{c}$ & $3.0 \mathrm{~d}$ \\
\hline With buds (\%) & $8.6 \mathrm{~d}$ & $14.8 \mathrm{c}$ & $28.3 \mathrm{~b}$ & $87.9 \mathrm{a}$ \\
\hline \multicolumn{5}{|l|}{1986 On } \\
\hline Total $(\mathrm{kg})$ & $18.1 \mathrm{a}$ & $17.5 a$ & $6.8 \mathrm{~b}$ & $5.5 c$ \\
\hline With buds (\%) & $43.0 \mathrm{a}$ & $33.5 \mathrm{~b}$ & $29.6 \mathrm{c}$ & $10.6 \mathrm{~d}$ \\
\hline \multicolumn{5}{|l|}{1987 Off } \\
\hline Total $(\mathrm{kg})$ & $6.0 \mathrm{a}$ & $4.7 \mathrm{a}$ & $2.6 \mathrm{~b}$ & $2.7 \mathrm{~b}$ \\
\hline With buds (\%) & $32.6 \mathrm{~b}$ & $40.1 \mathrm{~b}$ & $81.1 \mathrm{a}$ & $83.6 \mathrm{a}$ \\
\hline \multicolumn{5}{|l|}{1988 On } \\
\hline Total $(\mathrm{kg})$ & $4.9 \mathrm{a}$ & $4.8 \mathrm{a}$ & $7.5 \mathrm{a}$ & $9.0 \mathrm{a}$ \\
\hline With buds (\%) & $39.4 \mathrm{a}$ & $32.4 a$ & $10.3 \mathrm{~b}$ & $9.6 b$ \\
\hline \multicolumn{5}{|l|}{1989 Off } \\
\hline Total $(\mathrm{kg})$ & $3.5 \mathrm{a}$ & $3.8 \mathrm{a}$ & $2.7 \mathrm{a}$ & $3.2 \mathrm{a}$ \\
\hline With buds (\%) & $46.7 \mathrm{~b}$ & $38.6 \mathrm{~b}$ & $84.1 \mathrm{a}$ & $81.2 \mathrm{a}$ \\
\hline \multicolumn{5}{|l|}{$1990 \mathrm{On}$} \\
\hline Total $(\mathrm{kg})$ & $2.4 \mathrm{a}$ & $2.6 \mathrm{a}$ & $3.3 \mathrm{a}$ & $5.4 a$ \\
\hline With buds (\%) & $37.9 \mathrm{a}$ & $27.8 \mathrm{a}$ & $17.9 \mathrm{a}$ & $15.8 \mathrm{a}$ \\
\hline \multicolumn{5}{|l|}{1991 Off } \\
\hline Total (kg) & $1.0 \mathrm{~b}$ & $1.2 \mathrm{ab}$ & $1.4 \mathrm{ab}$ & $1.6 \mathrm{a}$ \\
\hline With buds $(\%)$ & $81.1 \mathrm{~b}$ & $88.4 a b$ & $88.8 \mathrm{ab}$ & $90.5 a$ \\
\hline
\end{tabular}

${ }^{2}$ Mean separation within rows by Duncan's new multiple range test $(P \leq 0.05)$.

Table 4. Effect of mechanical pruning on annual percent increase in girth growth. ${ }^{2}$

\begin{tabular}{lcccr}
\hline \hline & \multicolumn{4}{c}{ Pruning method } \\
\cline { 2 - 5 } $\begin{array}{l}\text { Year } \\
\text { and cycle }\end{array}$ & $\begin{array}{c}\text { Hedged/ } \\
\text { topped }\end{array}$ & Topped & Hedged & $\begin{array}{c}\text { Hand } \\
\text { (control) }\end{array}$ \\
\hline 1985 Off & $5.5 \mathrm{c}$ & $6.3 \mathrm{~b}$ & $6.3 \mathrm{~b}$ & $7.3 \mathrm{a}$ \\
1986 On & $5.0 \mathrm{a}$ & $4.5 \mathrm{~b}$ & $4.0 \mathrm{c}$ & $3.3 \mathrm{~d}$ \\
1987 Off & $6.4 \mathrm{~b}$ & $7.1 \mathrm{~b}$ & $8.7 \mathrm{a}$ & $8.8 \mathrm{a}$ \\
1988 On & $6.3 \mathrm{a}$ & $5.9 \mathrm{a}$ & $3.6 \mathrm{c}$ & $4.9 \mathrm{~b}$ \\
1989 Off & $5.9 \mathrm{~b}$ & $6.0 \mathrm{~b}$ & $7.9 \mathrm{a}$ & $7.4 \mathrm{a}$ \\
1990 On & $11.8 \mathrm{a}$ & $10.2 \mathrm{a}$ & $11.0 \mathrm{a}$ & $10.4 \mathrm{a}$ \\
1991 Off & $4.8 \mathrm{~b}$ & $5.3 \mathrm{~b}$ & $7.1 \mathrm{a}$ & $6.9 \mathrm{a}$
\end{tabular}

${ }^{\overline{2}}$ Mean separation within rows by Duncan's new multiple range test $(P<0.05)$

\section{Literature Cited}

Beede, R.H., L. Ferguson, D. Rose, and J. Padilla. 1991, Effect of pruning on the yield components of pistachio. California Pistachio Industry, Annu. Rpt.. Crop Year 1990-91. p. 90-93.

Beede, R.H., D. Rose, J. Padilla, and D. Thomas. 1992. Growth response from "on" year pruning and its effect on pistachio yield and nut quality for the following "off" year. California Pistachio Industry, Annu. Rpt., Crop Year 1991-92. p. $127-131$.

California Pistachio Commission. 1990. United
States standards for grades of pistachio nuts. California Pistachio Commission. Quality Grades and Handling Guide. Fresno, Calif.

Crane. J.C. and I. Al-Shalan. 1977. Carbohydrate and nitrogen levels in pistachio branches as related to shoot cxtension and yield. J. Amer. Soc. Hort. Sci. 102:396-399.

Crane, J.C., I. Al-Shalan, and R.M. Carlson. 1973. Abscission of pistachio infloresence buds as affected by leaf area and number of nuts. J. Amer. Soc. Hort. Sci. 98:591-592.

Crane, J.C., P.B. Catlin, and I. Al-Shalan. 1976. Carbohydrate levels in the pistachio as related to alternate bearing. J. Amer. Soc. Hort. Sci. 101:371-374.

Crane. J.C. and B.T. Iwarkiri. 1986. Yield and quality of pistachio as affected by rootstock. HortScience 21:1139-1140.

Crane, J.C., B.T. Iwakiri. and T. Lin. 1982. Effects of ethephon on shell dehiscence and flower bud abscision in pistachio. HortScience 17:383384.

Crane. J.C. and M.M. Nelson. 1971. The unusual mechanism of alternate bearing in the pistachio. HortScience 6:489-490.

Crane, J.C. and M.M. Nelson. 1972. Effect, of crop load, girdling, and auxin application on alternate bearing of the pistachio. J. Amer. Soc. Hort. Sci. 97:337-339.

Ferguson. L. and J. Maranto. 1989. Effect of growth regulators on pistachio inflorescence bud retention. California Pistachio Industry. Annu. Rpt., Crop Year 1988-89. p. 91-92.

Goldschmidt, E.E. and A. Golomb. 1982. The carbohydrate balance of alternate-bearing citrus trees and the significance of reserves for flowering and fruiting. J. Amer. Soc. Hort. Sci. 107:206208.

MacDonald, J.D. and L. Balkan. 1901. Factors influencing the spread and severity of Verticillium wilt in pistachio. California Pistachio Industry, Annu. Rpt., Crop Year 1989-90. p. 98101.

Monselise, S.P. and E.E. Goldschmidt. 1982. Alternate bearing in fruittrees. Hort. Rev. 4: 128-173.

Niven, C.M., A. Fabbri, L. Dallo, V. Polite, P. Metheney, L. Ferguson, H. Cruz, W. Bentley, and B. Blackwell. 1994. Investigation of "damage by other means" in developing pistachios. California Pistachio Industry, Annu. Rpt.. Crop Year 1993-94. p. 87-91.

Smith, P.F. 1976. Collapse of 'Murcott' tangerine trees. J. Amer. Soc. Hort. Sci. 101:23-25.

Takeda, F., K. Ryugo, and J.C. Crane. 1980. Translocation and distribution of 14C-photosynthates in bearing and non-bearing pistachio branches. J. Amer. Soc. Hort. Sci. 105:642-644.

Weinbaum, S.A., G.A. Picchioni. T.T. Muraoka, L. Ferguson, and P.H. Brown. 1994. Fertilizer nitrogen and boron uptake, storage, and allocation vary during the alternate-bearing cycle in pistachio trees. J. Amer. Soc. Hort. Sci. 119:24-31.

Wolpert, J.A. 1986. Research in nitrogen and potassium nutrition and preliminary results on pruning of 13-year-old trees. California Pistachio Industry, Annu. Rpt.. Crop Year 1985-986. p. 80-85.

Wood. B.W. 1989. Pecan production responds to root carbohydrates and rootstock. J. Amer. Soc. Hort. Sci. 114:223-228. 